\title{
SELECTION OF EFFECTIVE DEMULSIFYING AGENTS FOR OIL-WATER EMULSIONS BREAKDOWN
}

\author{
BAYAMIROVA RYSKOL ${ }^{a}$, TOGASHEVA ALIYAa, ZHOLBASSAROVA \\ AKSHYRYN ${ }^{a}$, BISSENGALIEV MAX ${ }^{b}$, KUNAYEVA GAUKHAR ${ }^{a}$, \\ KULIYEV MURAD ${ }^{a}$, BORIBEK SHYNGGYS ${ }^{a}$
}

\begin{abstract}
Crude oil processing often requires the extraction of large amounts of water. Crude oil often mixes with water to form water-in-crude oil emulsions as a result of exposure such as high shear at the wellhead and natural surfactants in crude oil. These emulsions are undesirable and require demulsification to remove dispersed water and associated inorganic salts in order to meet production and shipping specifications. In addition, demulsifying these crude oil emulsions reduces corrosion and catalyst and consistently maximizes the overall profitability of crude oil production. The article looks into the results of tests on the selection of a demulsifier for the breakdown of waterin-oil emulsion mixtures at different settling times and temperatures depending on the specific consumption of the chemical agent, the effect of various demulsifiers on emulsions breakdown. The process of oil desalination with and without the addition of demulsifiers is considered. Desalination is carried out stepwise. Research results have shown that proxanol $305 / 50$ is the most effective demulsifier.
\end{abstract}

Key words: oil-water emulsion; demulsifier; demulsification; residual water; dewatering.

\section{INTRODUCTION}

In the process of oil production and its joint movement with formation water, stable oil emulsions with high water content are formed. The reason for the formation of oil emulsions is the effective mixing of oil with formation water in the wellbore when it rises to the surface of the earth and during further movement along the field utilities. The most common emulsion in the

\footnotetext{
a Yessenov University, Faculty of Engineering, 32 microdistrict, 130003 Aktau, Kazakhstan

${ }^{b}$ Atyrau University of Oil and Gas, Faculty of Oil and Gas, md.Railway station, st. Baimukhanova, 45A, Atyrau, Kazakhstan

*Corresponding autor: ainura_302015@mail.ru
} 
oil and gas industry is water in oil. The process of dispersing water droplets in oil is facilitated by the presence of surface acting agents (SAA) in the oil, such as asphaltenes, paraffins, resins and naphthenic acids. These SAAs are suspended in oil [1-3]. The concentration of these natural SAAa, which affect the stability of the oil-water emulsion, is higher in heavy oil than in light oil [4]. The quality of the oil produced, as is known, along with other indicators, is determined by its moisture content. The moisture content in the original product ranges from $90 \%$ to $0.1 \%$. The quality of crude oil is also determined by the salt content, which ranges from a few $\mathrm{mg} / \mathrm{l}$ to a few $\mathrm{g} / \mathrm{l}$. Water and salts present in oil cause a number of difficulties during transportation and processing. The effectiveness of the used demulsifying agent is the main factor in solving the problems of collecting and treating oil. Currently, the range of modern demulsifiers is wide. However, it is often impossible to achieve the required dewatering depth in the gathering system of oil wells and in the preparation process. With an increase in the share of high-viscosity oils and an increase in the average water-cut of oils this problem is acutely manifested in the total volume of production. The use of composites is several times more effective than the use of any compound in its pure form.

Oil treatment units (OTU) are used for dewatering and desalting oils. In addition, at these units measures are taken to reduce the ability of oil to evaporate (in order to reduce the loss of light hydrocarbons), i.e. oil stabilization is in progress.

It is most expedient to install OTU at points of maximum oil concentration in the field, for example, in tank farms. Taking into account the adopted scheme for gathering and transporting oil and gas, it is necessary to envisage the possibility of oil preparation at another field if an accident occurs at this field. Formation water produced with oil and with salts dissolved in it should be removed at the fields. In this case, the main processes are dewatering and desalination. Most of the salts are removed along with water during dewatering. However, in order to prevent corrosion of equipment, the formation of salt deposits and other disturbances in the process of oil refining, its deep desalination is required. Before desalination, fresh water is supplied to the oil as a result of which an artificial emulsion is formed which then undergoes destruction [5].

The process of breakdown of oil emulsions consists in merging of droplets of water dispersed in oil in the presence of a demulsifier and deposition of enlarged droplets.

Demulsifiers are surface acting agents that are adsorbed on the surface of water globules and form an adsorption layer with significantly lower mechanical strength, which facilitates droplet coalescence and contributes to the destruction of oil emulsions. 
The following types of demulsifiers are used: diproxamine, proxamine, disolvan, separol, polyacrylamide, oxyethylated compound OC, etc. Demulsifier should meet the following requirements: be highly active at low specific consumption; dissolve well in water or oil; be cheap and transportable; do not deteriorate the quality of oil; do not change its properties with temperature changes. Demulsification effect depends on the intensity of mixing of the demulsifier with the emulsion and on the temperature of the mixture. Demulsifiers are supplied by dosing pumps [6].

\section{RESULTS AND DISCUSSIONS}

Table 1. Thermochemical breakdown of emulsions at consumption of $20 \mathrm{mg} / \mathrm{l}$ $(n=1500 \mathrm{rpm}$

\begin{tabular}{|l|c|c|c|}
\hline \multicolumn{1}{|c|}{ Demulsifier description } & \multicolumn{2}{|c|}{$\begin{array}{c}\text { Amount of separated } \\
\text { water at time, min }\end{array}$} & $\begin{array}{c}\text { Residual water } \\
\text { content, \% }\end{array}$ \\
\cline { 2 - 3 } & \multicolumn{6}{|c|}{$\mathbf{1 2 0}$} & $\mathbf{1 2 0}$ & \\
\hline & \multicolumn{2}{|c|}{ Separated water, ml } & \\
\hline Without chemical agent & 71 & 73 & 3.2 \\
Diproxamine 157-65M & 78 & 82 & 1.9 \\
Reapon 4B & 65 & 73 & 2.9 \\
Proxanol 305* & 25 & 82 & 2.1 \\
Disolvan 4411 & 81 & 90 & 1.0 \\
\hline
\end{tabular}

Note: ${ }^{*}-100 \%$ chemical agent was used.

As follows from the experiments, the use of demulsifiers increases the depth of emulsion breakdown and reduces the residual water content in oil. However, the assumed consumption of $20 \mathrm{mg} / \mathrm{l}$ does not provide a reduction in residual water content below $1.0 \%$. Therefore, in the next series of experiments the consumption of these demulsifiers was increased to 50 $\mathrm{mg} / \mathrm{l}$ (see Table 2).

As can be seen from the Tables, with the increase in the consumption of demulsifiers (proxanol 305 and disolvan 4411), the residual water content in oil was below $1 \%$. The most effective is disolvan 4411 (consumption up to $50 \mathrm{mg} / \mathrm{l})$. Proxanol 305 is also acceptable.

Demulsifier consumption of $100 \mathrm{mg} / \mathrm{l}$ (at proxanol 305) is the initial one for the production of pilot tests and in the process of commissioning and testing of OTU mode can be reduced. The preferred point for demulsifier injection is before the gas separators of OTU and before the process pump of the oil dewatering stage. 
BAYAMIROVA RYSKOL, TOGASHEVA ALIYA, ZHOLBASSAROVA AKSHYRYN, BISSENGALIEV MAX, KUNAYEVA GAUKHAR, KULIYEV MURAD, BORIBEK SHYNGGYS

Table 2. Thermochemical breakdown of emulsions at consumption of $50 \mathrm{mg} / \mathrm{l}$ $(\mathrm{n}=1000 \mathrm{rpm})$

\begin{tabular}{|l|c|c|}
\hline \multicolumn{1}{|c|}{ Demulsifier description } & $\begin{array}{c}\text { Amount of separated } \\
\text { water at time, min }\end{array}$ & $\begin{array}{c}\text { Residual water } \\
\text { content, \% }\end{array}$ \\
\cline { 2 - 2 } & $\mathbf{1 2 0}$ & \\
\hline & Separated water, ml & \\
\hline Without chemical agent & 90 & 2.3 \\
Diproxamine 157-65M & 90 & 2.1 \\
Reapon 4B & 85 & 3.8 \\
Proxanol 305* & 95 & traces-0.5 \\
Disolvan 4411 & 100 & traces \\
\hline
\end{tabular}

Note: * $100 \%$ chemical agent was used.

The end of the mass transfer of the demulsifier with the emulsion stabilizer is carried out when passing through the heat exchanger. Thus, the following parameters can be recommended to arrange the process of dewatering of a mixture of oil and condensate at the Karachaganak field:

Oil-water emulsion heating temperature

$60 . .70^{\circ} \mathrm{C}$;

Settling temperature

$60 \ldots 70^{\circ} \mathrm{C}$

Demulsifier initial consumption

Demulsifier brand

$50 . .100 \mathrm{mg} / \mathrm{l}$;

proxanol 305, disolvan 4411;

Time in settling pit up to 1 hour.

Compatibility of the demulsifier with wax inhibitors and corrosion inhibitors during dewatering

The compatibility of the inhibitors IKIG, Sever-1, Tyumen-2 and Neftekhim Зв and the effect on the demulsification process of oil-water-gas condensate emulsion when using the demulsifier proxanol 305-50 were studied. The studies were carried out according to the methodology presented above with the selected parameters.

In the course of the study the influence of the "aging" of the emulsion on the process of emulsion breakdown was also assessed.

The study results are given in the Table 3.

From the Table 3 it follows that aging significantly affects the depth of emulsion breakdown both with demulsifier and with the combined presence of demulsifier with a number of corrosion and wax inhibitors. 
It is also seen from the experiments that the most preferred additives are inhibitors of the IKIPG type which practically do not affect the demulsifying activity of the selected demulsifier. The situation is somewhat worse with the compatibility of proxanol 305-50 and corrosion inhibitor such as imidozoline (Tyumen-2, Neftekhim 3в) and pyridones (Sever-1). However, it should be noted here that in the experiments we used a 2 -fold reduction in the consumption of the demulsifier. This technique was used for a better manifestation of antagonism or synergy in the combined presence of demulsifier and inhibitor, and hence a more accurate assessment. With an increase in proxanol consumption the observed antagonism is suppressed due to its competing adsorption on globules of formation water in oil and peptization of the displaced asphaltene-paraffinic emulsion stabilizers.

Table 3. The amount of separated water

\begin{tabular}{|c|c|c|c|c|c|}
\hline \multirow{2}{*}{$\begin{array}{l}\text { Chemical } \\
\text { agent brand }\end{array}$} & \multirow{2}{*}{$\begin{array}{c}\text { Agent } \\
\text { consumption, } \\
\mathrm{mg} / \mathrm{l}\end{array}$} & \multicolumn{2}{|c|}{ "Fresh" emulsion } & \multicolumn{2}{|c|}{ After its aging } \\
\hline & & $\begin{array}{c}\text { Amount of } \\
\text { separated } \\
\text { water, } \%\end{array}$ & $\begin{array}{c}\text { Residual } \\
\text { water } \\
\text { content, \% }\end{array}$ & $\begin{array}{c}\text { Amount of } \\
\text { separated } \\
\text { water, } \%\end{array}$ & $\begin{array}{c}\begin{array}{c}\text { Residual } \\
\text { water } \\
\text { content, } \%\end{array} \\
\end{array}$ \\
\hline 1 & 2 & 3 & 4 & \begin{tabular}{l|l}
5 & \\
\end{tabular} & 6 \\
\hline Proxanol & $\begin{array}{c}50 \\
100\end{array}$ & $\begin{array}{c}100 \\
-\end{array}$ & $\begin{array}{c}\text { traces } \\
-\end{array}$ & $\begin{array}{l}75 \\
95\end{array}$ & $\begin{array}{l}2.5 \\
0.5\end{array}$ \\
\hline $\begin{array}{l}\text { Agent } \\
\text { mixtures: } \\
\text { Proxanol 305+ } \\
\text { IKIPG }\end{array}$ & $\begin{array}{c}50 \\
400\end{array}$ & 100 & traces & 100 & traces \\
\hline $\begin{array}{l}\text { Proxanol 305+ } \\
\text { IKIPG+ } \\
\text { GKP-86 }\end{array}$ & $\begin{array}{c}50 \\
200 \\
400\end{array}$ & 91 & 0,9 & 93 & 0.7 \\
\hline $\begin{array}{l}\text { Proxanol 305+ } \\
\text { Sever-1 }\end{array}$ & $\begin{array}{c}50 \\
200 \\
\end{array}$ & 97 & 0,3 & 67 & 3.3 \\
\hline $\begin{array}{l}\text { Proxanol 305+ } \\
\text { Tyumen-2 }\end{array}$ & $\begin{array}{c}50 \\
100\end{array}$ & 100 & traces & 82 & 1.8 \\
\hline $\begin{array}{l}\text { Proxanol 305+ } \\
\text { Neftekhim 3B }\end{array}$ & $\begin{array}{c}50 \\
100\end{array}$ & 100 & traces & 85 & 1.5 \\
\hline
\end{tabular}

Studies of the conditions of desalination were carried out taking into account the complicating factors, which include the formation of finely dispersed stabilized drops of formation water. The results of the study of emulsions "aging" are shown in the Table 4,5. 
BAYAMIROVA RYSKOL, TOGASHEVA ALIYA, ZHOLBASSAROVA AKSHYRYN, BISSENGALIEV MAX, KUNAYEVA GAUKHAR, KULIYEV MURAD, BORIBEK SHYNGGYS

Table 4. Desalting of the base oil-condensate mixture of the Karachaganak field without demulsifiers

\begin{tabular}{|c|c|c|c|c|c|c|c|}
\hline \multicolumn{5}{|c|}{ Stage 1} & \multicolumn{3}{|c|}{ Stage 2} \\
\hline \multirow{2}{*}{$\begin{array}{l}\text { Amount } \\
\text { of flush } \\
\text { water } \%\end{array}$} & \multirow{2}{*}{$\begin{array}{l}\text { Type } \\
\text { of } \\
\text { water }\end{array}$} & \multicolumn{2}{|c|}{$\begin{array}{c}\text { Elimination in } \\
2 \mathrm{~h}, \%\end{array}$} & \multirow{2}{*}{$\begin{array}{c}\text { Salt } \\
\text { content in } \\
\text { oil, } \mathrm{mg} / \mathrm{l}\end{array}$} & \multicolumn{2}{|c|}{$\begin{array}{c}\text { Elimination in } \\
2 \mathrm{~h}, \%\end{array}$} & \multirow{2}{*}{$\begin{array}{c}\text { Salt } \\
\text { content } \\
\text { in oil, } \\
\text { mg/l }\end{array}$} \\
\hline & & $\begin{array}{l}\text { Water, } \\
\text { ml }\end{array}$ & $\begin{array}{l}\text { intermedi } \\
\text { ate layer }\end{array}$ & & $\begin{array}{l}\text { Water, } \\
\mathrm{ml}\end{array}$ & $\begin{array}{l}\text { intermedi } \\
\text { ate layer }\end{array}$ & \\
\hline 15 & B1 & 12.5 & 1.5 & 9.7 & - & - & - \\
\hline 15 & B2 & 13.0 & 2.0 & 20.0 & - & - & - \\
\hline 15 & B3 & 3.0 & 0.5 & 23.2 & - & - & - \\
\hline 15 & B1 & 13.0 & 2.0 & & 14.0 & - & 4.0 \\
\hline 15 & B2 & 13.0 & 2,0 & & 13.0 & 1.0 & 4.0 \\
\hline 5 & B3 & 4.0 & 1.0 & & 4.0 & 1.0 & 7.2 \\
\hline
\end{tabular}

Table 5. Desalting of the base oil-condensate mixture of the Karachaganak field using proxanol 305/50

\begin{tabular}{|c|c|c|c|c|c|c|c|}
\hline \multicolumn{5}{|c|}{ Stage 1} & \multicolumn{3}{|c|}{ Stage 2} \\
\hline \multirow{2}{*}{$\begin{array}{l}\text { Amount } \\
\text { of flush } \\
\text { water \% }\end{array}$} & \multirow{2}{*}{$\begin{array}{l}\text { Type } \\
\text { of } \\
\text { water }\end{array}$} & \multicolumn{2}{|c|}{$\begin{array}{c}\text { Elimination in } \\
2 \mathrm{~h}, \%\end{array}$} & \multirow{2}{*}{$\begin{array}{c}\text { Salt } \\
\text { content } \\
\text { in oil, } \\
\text { mg/l }\end{array}$} & \multicolumn{2}{|c|}{$\begin{array}{c}\text { Elimination in } \\
2 \mathrm{~h}, \%\end{array}$} & \multirow{2}{*}{$\begin{array}{c}\text { Salt } \\
\text { content } \\
\text { in oil, } \\
\mathrm{mg} / \mathrm{l}\end{array}$} \\
\hline & & $\begin{array}{c}\text { Water, } \\
\text { ml }\end{array}$ & $\begin{array}{c}\text { Interme } \\
\text { diate layer }\end{array}$ & & $\begin{array}{c}\text { Water, } \\
\mathrm{ml}\end{array}$ & $\begin{array}{l}\text { intermedi } \\
\text { ate layer }\end{array}$ & \\
\hline 15 & B1 & 13.0 & 2.0 & 12.2 & - & - & - \\
\hline 15 & B2 & 14.0 & 1.0 & 11.0 & - & - & - \\
\hline 15 & B3 & 2.0 & 3.0 & 9.4 & - & - & - \\
\hline 15 & B1 & 13.5 & 2.0 & & 14.0 & Pit & 3.0 \\
\hline 15 & B2 & 14.0 & 1.0 & & 14.0 & Pit & 3.3 \\
\hline 5 & B3 & 2.5 & 2.5 & & 3.0 & 0.8 & 8.8 \\
\hline
\end{tabular}

Table 6. Desalting of the base oil-condensate mixture of the Karachaganak field using reapon $4 \mathrm{~B}$

\begin{tabular}{|c|c|c|c|c|c|c|c|}
\hline \multicolumn{5}{|c|}{ Stage 1} & \multicolumn{3}{|c|}{ Stage 2} \\
\hline \multirow{2}{*}{$\begin{array}{c}\text { Amount } \\
\text { of flush } \\
\text { water, \% }\end{array}$} & \multirow{2}{*}{$\begin{array}{l}\text { Type } \\
\text { of } \\
\text { water }\end{array}$} & \multicolumn{2}{|c|}{$\begin{array}{c}\text { Elimination in } \\
2 \mathrm{~h}, \%\end{array}$} & \multirow{2}{*}{$\begin{array}{c}\text { Salt } \\
\text { content } \\
\text { in oil, } \\
\text { mg/l }\end{array}$} & \multicolumn{2}{|c|}{$\begin{array}{c}\text { Elimination in } \\
2 \mathrm{~h}, \%\end{array}$} & \multirow{2}{*}{$\begin{array}{c}\text { Salt } \\
\text { content in } \\
\text { oil, mg/l }\end{array}$} \\
\hline & & $\begin{array}{c}\text { Water } \\
, \mathrm{ml}\end{array}$ & $\begin{array}{l}\text { intermedi } \\
\text { ate layer }\end{array}$ & & $\begin{array}{l}\text { Water } \\
\text {,ml }\end{array}$ & $\begin{array}{l}\text { ntermedi } \\
\text { ate layer }\end{array}$ & \\
\hline 15 & B1 & 13.0 & 2.0 & 15.0 & - & - & - \\
\hline 15 & B2 & 12.0 & 3.0 & 15.4 & - & - & - \\
\hline 15 & B3 & 2.0 & 3.0 & 16.0 & - & - & - \\
\hline 15 & B1 & 13.0 & 2.0 & - & 15.0 & Pit & 4.0 \\
\hline 15 & B2 & 12.0 & 3.0 & - & 14.0 & 2.0 & 8.8 \\
\hline 5 & B3 & 2.0 & 2.0 & - & 3.0 & 2.0 & 9.2 \\
\hline
\end{tabular}


Thus, the established demulsifier consumption should be dispersed along the process scheme in the direction of decreasing the emulsion aging time. In this, most of the demulsifier is used after the II stage separators $(\sim 60 \mathrm{mg} / \mathrm{l})$, and a smaller part is fed to the intake of the process pump of the dewatering stage $(40 \mathrm{mg} / \mathrm{l})$. This recommendation has constitutive nature for assigning an initial consumption when commissioning a dewatering process.

\section{CONCLUSIONS}

Emulsions of oil condensate and water are relatively unstable and are destroyed by simple heating up to $60^{\circ} \mathrm{C}$ to $2 \ldots 5 \%$ by residual water content, however, as emulsions age, their stability increases, which requires special treatment with demulsifiers. Demulsifier injection should be dispersed along the process scheme in the direction of decreasing the aging time of the emulsion;

For successful demulsification of oil in the electric dehydrator, the rated power of the transformer should be greater than the rated active power required to maintain the electric field of the required strength. For oil from the Karachaganak field this condition is fulfilled, which makes it possible to use electric dehydrators for the preparation of oil and its mixture with condensate. In this case, the power of the standard transformer of the EG 200-10 electric dehydrator can be reduced substantially;

All investigated chemical agents used in oil production and collection (except for Sever-1) do not significantly affect the stability of emulsions.

Introduction of the optimal type of demulsifying agent in the amount not exceeding $50 \mathrm{mg} / \mathrm{l}$ is mandatory both for reasons of completeness of the dehydration process and in terms of desalination indicators.

- considering that a significant part of the KNGKM salts are in a difficultto-recover form, the process temperature should be at least $70 \ldots 75^{\circ} \mathrm{C}$;

- the required completeness of separation of the emulsion requires the use of intensifying factors. The simplest and most effective is the electric field. An additional factor for the intensification of desalination can be the addition of a salt inhibitor to the flush water.

\section{EXPERIMENTAL SECTION}

The study used the most stable emulsion with a water content of $10 \%$ and an oil-condensate ratio of $1: 2$. The prepared emulsion after 16 hours of aging was heated to $60^{\circ} \mathrm{C}$, and a demulsifier was added with stirring. The stirring time was 5 minutes, which, due to its low viscosity, turned out to be 
BAYAMIROVA RYSKOL, TOGASHEVA ALIYA, ZHOLBASSAROVA AKSHYRYN, BISSENGALIEV MAX, KUNAYEVA GAUKHAR, KULIYEV MURAD, BORIBEK SHYNGGYS

sufficient to complete the processes of mass exchange of the demulsifier and stabilizer substances on the globules of dispersed water. After that, the emulsion was left to settle at the temperature of $60^{\circ} \mathrm{C}$ for 2 hours. At the end of the settling process, the amount of water released from the emulsion was measured and the residual water cut was calculated using the formula [7-9]

$$
\mathrm{V}=\frac{\mathrm{B}-\mathrm{a}}{\mathrm{c}-\mathrm{B}} \cdot 100 \%
$$

where $\mathrm{V}$ - residual water content in oil, \%;

$\mathrm{c}$ - emulsion volume, $\mathrm{ml}$;

B - amount of water in original emulsion, $\mathrm{ml}$;

$\mathrm{a}$ - amount of separated water in original emulsion, $\mathrm{ml}$.

Demulsifiers of Kazan IA "Orgsintez" which are widely used in the field in the processing of light and paraffinic oils were taken as demulsifiers. These are diproxamine 157-65M, proxanol 305 and reapon 4в. For comparison, experiments were also carried out with an imported analogue of disolvan 4411 manufactured by Hoechst (Germany). Table 1 shows the results of the study of emulsion dewatering at the temperature of $60^{\circ} \mathrm{C}$ and the speed of mixing the emulsion with demulsifiers at $1500 \mathrm{rpm}$. The initial consumption of demulsifiers of all brands was constant $(20 \mathrm{mg} / \mathrm{l})$. Demulsifiers were introduced in the form of $1 \%$ aqueous solutions[10-13].

\section{REFERENCES}

1. Daniel-David, D.; Le Follotec, A.; Pezron, I.; Dalmazzone, C.; Noik, C.; Barre, L.; Komunjer, L. Oil Gas Sci. Technol. Rev. L'IFP 2008, 63, 165-173.

2. Kundu, P.; Paul, V.; Kumar, V.; Mishra, I.M. Chem. Eng. Res. Des. 2015,104, P 773-790.

3. Martínez-Palou, R.; Reyes, J.; Cerón-Camacho, R.; Ramírez-de-Santiago, M.; Villanueva, D.; Vallejo, A.A.; Aburto, J. Chem. Eng. Process. Process Intensif. 2015, 98, 112-122.

4. Wong, S.; Lim, J.; Dol, S. J. Pet. Sci. Eng. 2015,135, 498-504.

5. Dejam, M.; Hassanzadeh, H.; Chen, Z. AlChE J. 2015, 61, 3981-3995.

6. Abdulredha, M.M. Arab. J. Chem. 2018, 52, 258-264

7. Bayamirova R., Togasheva A., Zholbassarova A., Islamberdiyev Z., Studia UBB Chemia, 2020, 65, 233-244.

8. Salam, K.; Alade, A.;Arinkoola, A.; Opawale, A. J. Pet. Eng. 2013, P 793101. 
9. Kang, W.; Yin, X.; Yang, H.; Zhao, Y.; Huang, Z.; Hou, X.; Sarsenbekuly, B.; Zhu, Z.; Wang, P.; Zhang, X.; et al. Colloids Surf. A Physicochem. Eng. Asp. 2018, 545, 197-204.

10. Ongarbayev Y., Golovko A., Krivtsov E., Tileuberdi E., Imanbayev Y., Tuleutayev B., Mansurov Z., Studia UBB Chemia, 2014, 59, 57-64.

11. Mhatre, S.; Simon, S.; Sjöblom, J.; Xu, Z. Chem. Eng. Res. Des. 2018, 134, 117-129.

12. Imanbayev Y., Tileuberdi Y., Ongarbayev Y., Mansurov Z., Batyrbayev A., Akkazin Y., Krivtsov E., Golovko A., Rudyk S., Eurasian Chemico-Technological Journal, 2017,19, 147-154

13. Bissembayeva K., Aissayeva T., Zholbassarova A., Islamberdiyev Z., Bayamirova R., Togasheva A.//Inter.J. of Engineering and Technology(UAE) 2018, 7, 376-379 
